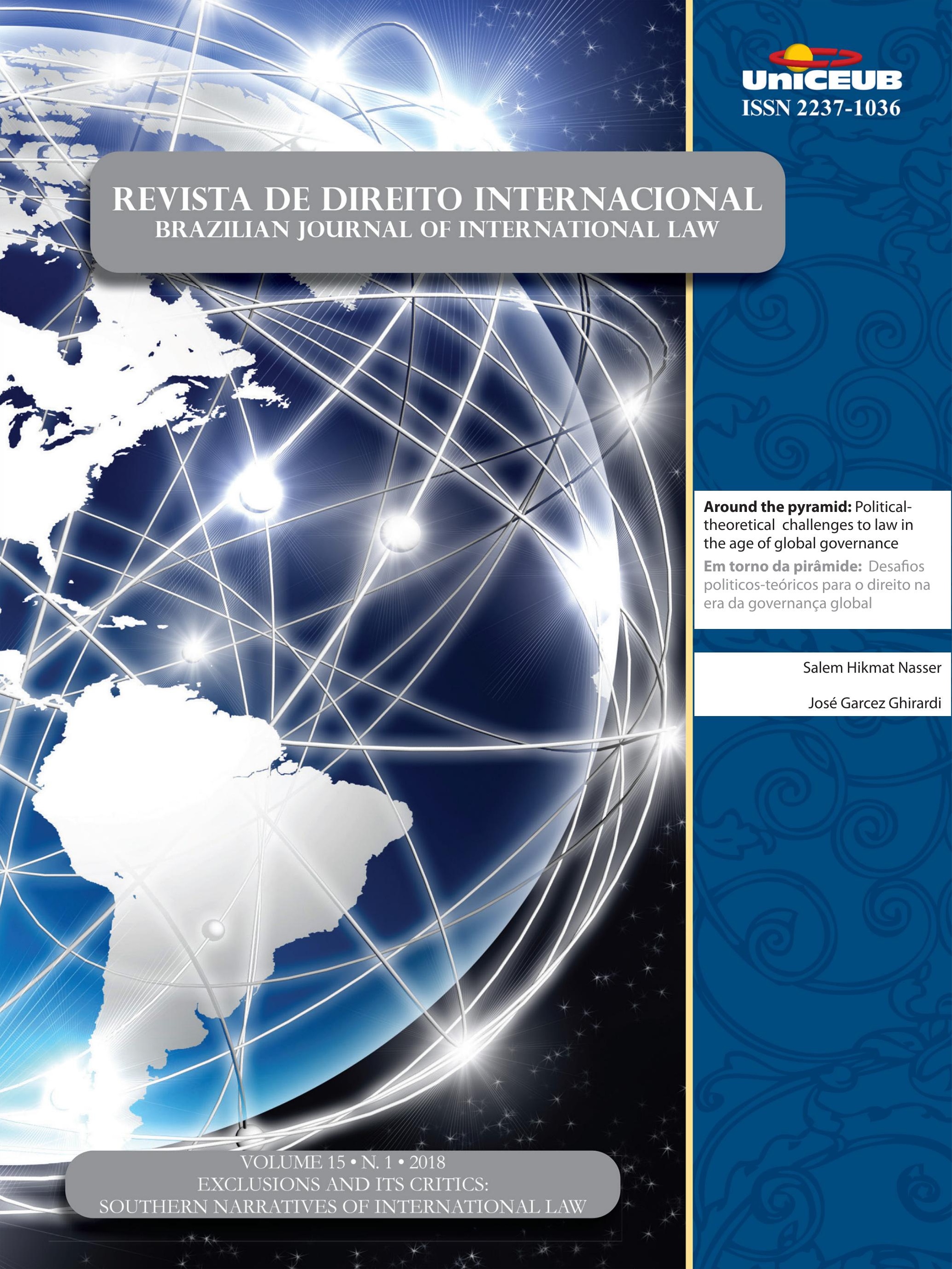




\section{Sumário}

I. Dossiê Especial: Exclusions and its Critics: Southern Narratives of

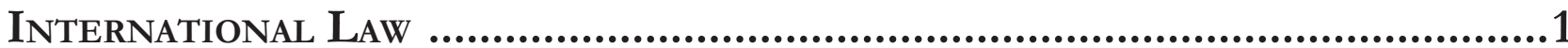

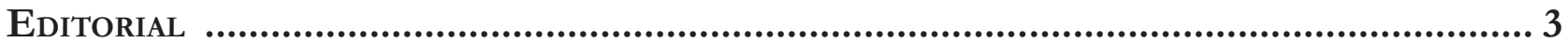

Conseguimos pensar em narrativas críticas do Direito Internacional no Sul Global? ......................... 3

ENTRE A APOLOGIA E A UTOPIA: A POLÍTICA Do DIREITO INTERNACIONAL................................ 6 Martti Koskenniemi e Tradutor João Roriz

A POLÍTICA Do DIREITO INTERNACIONAL: 20 ANOS DEPOIS ...................................................31 Martti Koskenniemi e Tradutor João Roriz

Abordagens terceiro-mundistas para o Direito Internacional: Um Manifesto............42 Bhupinder S. Chimni

Around the pyramid: Political-theoretical challenges to law in the age of global GOVERNANCE

Salem Hikmat Nasser e José Garcez Ghirardi

VOICE AND EXIT: HOW EMERGING POWERS ARE PROMOTING INSTITUTIONAL CHANGES IN THE INTERNATIONAL MONETARY SYSTEM

Camila Villard Duran

LA LIBRE AUTODETERMINACIÓN DE LOS PUEBLOS EN EL SIGLO XXI: UNA APROXIMACIÓN DE LA HISTORIA DEL COLONIALISMO Y EL NEO-COLONIALISMO DESDE LOS PUEBLOS DEL TERCER MUNDO

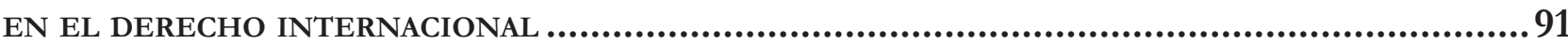

Germán Medardo Sandoval Trigo

INTERNATIONAL CLIMATE CHANGE REGIME AS A PROMOTER OF COLONIAL SYSTEMIC AND SYMBOLIC VIOLENCE: ITS RELATIONSHIP WITH INTERNATIONAL ENVIRONMENT SECURITY AND FOOD SYSTEM THRU THE LENS OF FEMINIST APPROACH 106

Douglas Castro e Bruno Pegorari 
Jus COGENS: AN EUROPEAN CONCEPT? AN EMANCIPATORY CONCEPTUAL REVIEW FROM THE INTER-AMERICAN SYSTEM OF HUMAN RIGHTS

Tatiana de A. F. R. Cardoso Squeff e Marina de Almeida Rosa

O CONHECIMENTO TRADICIONAL RELACIONADO AO COMPLEXO DO CURARE E A LEGISLAÇÃO IN-

TERNACIONAL SOBRE PROPRIEDADE INTELECTUAL. 139

Marcos Vinício Chein Feres e João Vitor de Freitas Moreira

II. Artigos sobre outros temas

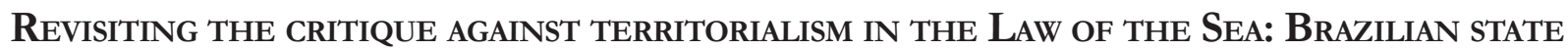
PRACTICE IN LIGHT OF THE CONCEPTS OF CREEPING JURISDICTION AND SPOLIATIVE JURISDICTION ..161 Victor Alencar Mayer Feitosa Ventura

EDUCAÇÃO SUPERIOR INTERCULTURAL, RECONHECIMENTO E REDISTRIBUIÇÃO: O DURO CAMINHO DOS POVOS INDÍGENAS NO EQUADOR 180

Vanessa Wendhausen Cavallazzi, Patrícia Perrone Campos Mello e Raony Soares

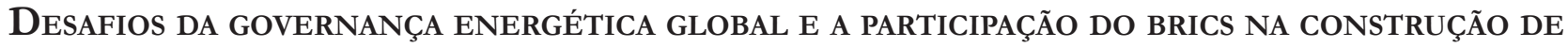
UM NOVO PARADIGMA ENERGÉTICO 200

Fernanda Volpon e Marilda Rosado de Sá Ribeiro

A hermeneutical analysis on the recognition of China as a market economy after 2016.

Alberto Amaral Júnior e Aline Pereira de Carvalho Heringer

THE ISIS ERADICATION OF CHRISTIANS AND YAZIDIS: HUMAN TRAFFICKING, GENOCIDE, AND THE MISSING INTERNATIONAL EFFORTS TO STOP IT

Sarah Myers Raben

The strategic prudence of The Inter-American Court of Human Rights: Rejection OF REQUESTS FOR AN ADVISORY OPINION 255

Cecilia M. Bailliet

Direito Internacional Monocromático: PREVISÃo e apliCaÇÃo dos Direitos LGBTI NA ORDEM INTERNACIONAL 278

Rafael Carrano Lelis e Gabriel Coutinho Galil 
III. RESENHAS

Resenha do livro Empire de Michael Hardt e Antonio Negri 301 Arthur Roberto Capella Giannattasio

Resenha do livro Imperialism, Sovereignty and the Making of International LaW, de

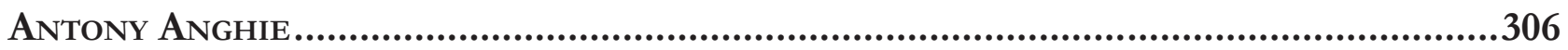

Fabrício José Rodrigues de Lemos e Laura Madrid Sartoretto 


\title{
Around the pyramid: Political-theoretical challenges to law in the age of global governance*
}

\author{
Em torno da pirâmide: Desafios politicos- \\ teóricos para o direito na era da governança \\ global
}

\author{
Salem Hikmat Nasser** \\ José Garcez Ghirardi***
}

\section{Abstract}

The idea of global governance has become central to debates on international relations. It has been hailed as the most performing strategy to articulate the multiple, concurring, sometimes conflicting interests of the increased number of global players. The relevance of this popularity goes much beyond the practical reasons often invoked in favor of its adoption. It bespeaks a process of a deep transformation of the very theoretical frameworks within which Law, in general, and international Law, in particular, have been conceived. This paper argues that prevailing understandings of global governance risk contributing to depoliticize the exchange between States, as it usually overemphasizes the supposedly technical, objective dimension of performance indexes while underemphasizing the political choices embodied in their design. It has as its main theoretical sources the works of OST and KERCHOVE ${ }^{1}$, SUPIOT ${ }^{2}$, FOUCAULT (1998), SOUSA SANTOS \& RODRIGUEZ-GARAVITO ${ }^{3}$.

* Recebido em 31/10/2017

Aprovado em 21/12/2017

** Full-time professor of International Law at FGV Direito SP. Doctorate in International Law from USP (Universidade de São Paulo). DEA in Public International Law and DSU in Private International Law from the University of Paris II (Panthéon-Assas). Visiting researcher at the Lauterpacht Centre for International Law and at the European University Institute. Email: salem.nasser@fgv.br

*** Lawyer. Bachelor of Law, Universidade de São Paulo (1985). Full-time professor at Direito SP/SP. MA and PhD in English Language and Literature, USP. Visiting researcher at the Collège de France, Chair Ètat Social et Mondialisation (2017). Adjunct Faculty at Gonzaga Law School (WA/USA) (2010; 2013) and visiting professor at IDC-Israel (2014). Visiting researcher at the Wayne State University (DetroitMI, USA) with a scholarship granted by CNPq. Postdoctoral research at the State University of Campinas (UNICAMP) (2003-2004). Email: jose.ghirardi@fgv.br
Keywords: global governance - international Law - depoliticization - rational choice

\section{Resumo}

A ideia da governança global se tornou central nos debates sobre relações internacionais. Ela tem sido proclamada como a estratégia com melhor desempenho na articulação de interesses múltiplos, concorrentes, e por vezes conflitantes de um número cada vez maior de atores globais. A relevância dessa popularidade vai muito além das razões práticas frequentemente evocadas a favor de sua adoção. Ela evidencia um processo de profunda transformação das próprias molduras teóricas dentro das quais o Direito,

1 OST, François; KERCHOVE, Michel van de. De la pyramide au réseau? Pour une théorie dialectique du droit. Bruxelles : Presses des Facultés Universitaires Saint Louis, 2002.

2 SUPIOT, Alain. La Gouvernance par les Nombres. Cours au Collège de France (2012 2014). Paris: Fayard - Poids et medures du monde, 2015.

3 DE SOUZA SANTOS, Boaventura; RODRIGUEZ-GARAVITO, César A(orgs). Law and Globalization from Below. Cambridge: Cambridge University Press, 2005. 
no geral, e o Direito Internacional, no particular, foram concebidos. Esse artigo sustenta que os entendimentos predominantes sobre a governança global correm o risco de contribuir para despolitizar as trocas entre os Estados, dado que em geral enfatizam a dimensão supostamente técnica e objetiva dos índices de desempenhos ao mesmo tempo que reduzem a importância das escolhas políticas incorporadas em seu desenho. $\mathrm{O}$ artigo tem como principais referências os trabalhos de OST e KERCHOVE, SUPIOT (2015), FOUCAULT (1998), SOUSA SANTOS \& RODRIGUEZ-GARAVITO (2005).

Palavras-chave: Governança Global - Direito Internacional - despolitização - escolhas racionais

\section{Neutrality and naturalization: ASSUMPTIONS OF THE DISCOURSE ON GLOBAL GOVERNANCE}

In their celebrated De la pyramide au réseau? Pour une théorie ialectique du droit, François Ost and Michel van de Kerchov suggest that the analysis of the transformations of Law in a post-modern, globalized world must take into account three interconnected elements:

\begin{abstract}
The sliding from pyramid to network is an evolution coupled with two other major transformations in the legal-political universe: the passage from ordinances to regulation and the strengthening of governance in face of government. Network, regulation and governance form thus a new device of which, though it would undoubtedly be excessive to say that it may replace the classic triad represented by pyramid, ordinances and government, certainly surpasses and subverts their mode of functioning. ${ }^{4}$
\end{abstract}

Ost and Kerchov's argument aptly synthetizes some of the key themes in the current academic debate on Law and institutions, namely: a) a broad, inevitable transformation is reshaping legal-political landscapes; b) this

\footnotetext{
4 «Le glissement de la pyramide au réseau est une évolution qui sraccompagne de deux autres transformations majeures de l>univers juridico-politique: le passage de la réglementation à la régulation, et la montée en puissance du thème de la gouvernance en lieu et place de celui du gouvernement. Réseau, régulation et gouvernance forment ainsi un nouveau dispositif dont il serait sans doute excessif de dire quil ssest substitué à la triade classique pyramide, réglementation, gouvernement, mais qui la déborde certainement et en subvertit parfois les modes de fonctionnement». OST, François ; KERCHOVE, Michel van de De la pyramide au réseau? Pour une théorie dialectique du droit. Bruxelles: Presses des Facultés Universitaires Saint Louis, 2002, p. 26 .
}

phenomenon both springs from and reinforces the enfeebling of the socio-political institutions inherited from Modernity; c) this enfeebling is due to the fact that such institutions have been proving themselves incapable of coping with the implications of globalization and of post-modern societal arrangements; d) new, emerging modes of social, political and economic exchanges hold a better chance of organizing present and future human interaction than their Modern ancestors. With marginal variations, these four points appear recurrently in contemporary scholarly appraisals of legal transformation. ${ }^{5}$

The argumentative framework within which such themes are developed is as emblematic of contemporary discourse as the themes themselves, articulating widely accepted axiological and methodological assumptions. The former have to do with the feasibility of separating description and assessment when discussing social phenomena. The latter have to do with an approach to such phenomena which involves what Foucault calls the naturalizing of society. ${ }^{6}$

In what regards the axiological assumptions, they bespeak the belief that it is possible to describe social events without evaluating them. From this point of view, one could neutrally depict a certain state of affairs, that is to say, without making any value judgment on the picture being presented. An observer would thus be able to say that the process of shifting is so without discussing whether it should be so, or whether it is desirable that it be so. Observation, description and evaluation would be three inter-connected, but ultimately distinct, moments.

Ost and Kechove seem to cautiously embrace these basic tenets, whose perils they nevertheless acknowledge:

\begin{abstract}
One last caveat must be made, axiological in nature. It aims at bringing to mind the basic distinction, from which one should never depart in social sciences, between describing, explaining and evaluating a situation. Describing and explaining legal situations with the help of the network method (and its corollaries, regulation and governance) does not mean to evaluate positively, nor to unconditionally approve such evolution. Without aiming at an (impossible) neutral stance, we will always strive to keep things separate: take note of an evolution when this seems undeniable, try to explain its causes and consequences and, afterwards, at the axiological level, make - if this is the case - a critical value judgment. ${ }^{7}$
\end{abstract}

5 LECHNER, Frank S.;BOLI, John. The Globalization Reader. 4th Edition. Wiley-Blackwell, 2011.

6 FOUCAULT, Michel. Sécurité, Territoire, Population; Gallimard, Paris, 2004.

7 Une dernière mise un garde s'impose, d'ordre axiologique. Elle 
The process thus presented is that of a gradual strengthening of the newcomers (network, regulation, governance) as well as a fading out of the old strongholds (pyramid, ordinances, government). It assumes a deep connection between new social needs and new legal-political forms. Crucially important, it suggests that this connection is an attempt by social players, albeit often tentative and not fully conscious, to find more suitable ways to carry on their interactions.

Implicit in this narrative is, therefore, the hypothesis that this shifting towards new forms is not accidental but motivated. Academic analyses of social transformations presuppose that things do not just change; they change for a reason. The search for this causal link is at the heart of their explanatory efforts. In what regards assessments of globalization and post-modernity, analyses have been typically framed around the notion of social adjustment.

This is a consequential argumentative choice. For the idea of adjustment implies a process of accommodation between conflicting elements, in the case at hand, between old (government, ordinances, pyramid) and new (governance, regulation, network) legal-political forms. This process involves the testing of different social dynamics and institutional designs and the assumption that some designs will be better than others in producing the necessary adjustment of things. This ranking between the quality of individual solutions is necessarily evaluative in nature, as it is true of any comparative construction.

The reference to an (impossible) neutral stance underscores, nevertheless, the perceived difficulty of separating the actions of describing and evaluating when it comes to Law and the social sciences. The idea that it is possible to keep things separate has been repeatedly called into question, as well as the viability of explaining

vise à rappeler la distinction élémentaire, dont il ne faut pas se départir en sciences sociale, entre décrire, expliquer, et évaluer une situation. Décrire et expliquer des situations juridiques à l'aide du modèle du réseau (et ses corollaires, la régulation et la gouvernance) ne signifie pas évaluer positivement, approuver de façon inconditionnelle cette évolution. Sans prétendre à une (impossible) neutralité, on s'efforcera toujours de faire la part des choses : prendre acte d'une évolution quand celle-ci paraît s'imposer, tenter d'en expliquer les raisons et les conséquences, et ensuite, au plan axiologique, prononcer s'il le faut un jugement de valeur critique. OST, François; KERCHOVE, Michel van de. De la pyramide au réseau? Pour une théorie dialectique du droit. Bruxelles: Presses des Facultés Universitaires Saint Louis, 2002. p. 19 (our translation) causes and consequences first, leaving value judgments for afterwards.

In the legal arena, the Fish-Dworkin dispute is perhaps the best-known example of the heated controversies around this problem. Against Dworkin's defense of the possibility of some disjunction between describing and assessing, ${ }^{8}$ Fish suggests that such distinction is untenable as these do not constitute two different actions but rather two dimensions of the same action ("information only comes in an interpreted form - it does not announce itself)".?

Current analyses of the transformations of Law have for the most part declined to tackle this issue, requiring readers (often, implicitly) to assume that it is conceivable to separate the description of social events and their moral and political evaluation. Their tacit understanding seems to be, as Ost and Kerchove argumentative drive illustrates, that though narrative neutrality may be impossible, moral-political neutrality is not. ${ }^{10}$

This silencing of their critical assumptions is of consequence to the very substance of such studies. The willing suspension of disbelief in neutrality (to borrow Coleridge's famous phrase), works to naturalize the diagnoses these studies advance and to veil the ideological tenets informing them. Given the fact that diagnoses may vary widely according to the viewpoint one adopts and that they form the ground basing theoretical explanations (and reform proposals for governments and States), such naturalizing appears highly problematic.

Historians have been particularly sensitive to this difficulty, often referred to as the narrativity issue, and to its deep implications for scientific discourse. Hayden White warns his fellow scholars that:

8 Dworkin presents even more clearly his argument in his illuminatingly entitled My reply to Stanley Fish (and Walter Benn Michaels): Please don't talk about objectivity any more in which he says Fish's reading of his previous work was simply « incompetent». MITCHELL, W. J. T (editor). The Politics of Interpretation (A critical Inquiry Book). Chicago: University of Chicago Press Journals, 1983. « My purpose was pragmatic. Once we understand how people can and do make these discriminations, then we can grasp the special character of enterprises, like law, in which people aim to interpret rather than invent» (pp. 287; 291). The successive, separable moments (once...then...) remain clear in his characteristically sophisticated reasoning.

9 FISH, Stanley. "Working on the Chain Gang: Interpretation in the Law and in Literary Criticism." Critical Inquiry, vol. 9, no. 1, 1982, p. 204. JSTOR, JSTOR, www.jstor.org/stable/1343280.

10 This concern with the problem of neutrality in assessments of globalization is far from being a methodological quiddity, as Ost and Kerchove's indicate by their elegant caveat. 
...it is precisely because the narrative mode of representation is so natural to buman consciousness, so much an aspect of everyday speech and ordinary discourse, that its use in any field of study aspiring to the status of a science must be suspect. For whatever else a science may be, it is also a practice which must be as critical about the way it describes its object of study as it is about the way it explains structures and processes. ${ }^{11}$

Contemporary accounts of shifts in Law face the same challenge of critically justifying the diagnoses they make, especially when they present themselves as anodyne renderings of reality. They have to validate their claim of judgment-free description vis-à-vis charges that such accounts must inevitably build themselves around value assessments (v.g. on what gets included or excluded, what is central and what is peripheral, what is cause and what is consequence in their version of change).

The fact that usually this methodological step remains rare (Ost and Kerchove being an outstanding exception) bears testimony to the depth of the belief in the possibility of morally and politically neutral descriptions of legal and societal changes. Thus, rather curiously, discourses on globalization and post-modernity often advance, if often without avowing it, by reaffirming the core belief of Modern science: an impartial observer describes, through a neutral means, an objective reality.

This axiological stance on the neutrality of the subject gets translated into a methodological strategy on the stability of the object presented. Society, in these accounts, is usually presented as a quasi-natural entity, thus becoming more suited to nentral diagnoses. In Society, Territory, Population, Michel Foucault describes at length the process by which this naturalization of social phenomena became a defining element in contemporary readings of the State and society.

For the author, the new forms of governmentality would be focused not on ruling " a set of legal subjects capable of voluntary actions" 12 but a population in the biological denotation of the term:

In other words, with the population we have something
completely different from a collection of subjects of
right differentiated by their status, localization, goods,
responsibilities, and offices: [We have] a set of elements that,

11 WHITE, Hayden. "The Question of Narrative in Contemporary Historical Theory." History and Theory, vol. 23, no. 1, 1984, p. 1.

12 FOUCAULT, Michel. Security, Territory, Population: Lectures at the Collège de France 1977-1978 Palgrave, 2009. pp. 36-37 on one side, are immersed within the general regime of living beings and that, on another side, offer a surface on which authoritarian, but reflected and calculated transformations can get a hold. The dimension in which the population is immersed amongst the other living beings appears and is sanctioned when, for the first time, men are no longer called "mankind (le genre humaine)" and begin to be called "the buman species (l'espèce bumaine).13

From this perspective, the behavior of the human species would be fundamentally as predictable as those of other living beings and this natural regularity would allow for calculated transformations. Crucially important, these transformations would be based on a primarily technical understanding of the forces shaping social interactions based on the so-called hard sciences. Governing would be gradually understood as an essentially technical, not political a task. Much of today's dissatisfaction with democracy arguably springs from just such a naturalizing reading of human affairs. ${ }^{14}$

John K. Galbraith's observations at the beginning of his popular The Age of Uncertainty are emblematic of such perspective. Galbraith argues that ideological differences are ultimately irrelevant to the definition of the best solutions for air pollution or inflation, for instance (as circumstances force us all to adopt the same attitude). If we want to survive and solve these problems, he proposes, we had better get rid of partisan political lenses, see things as they are and do what has to be done. ${ }^{15}$ This core belief continues to enjoy substantial prestige today, even if it is usually coated in less candid terms.

The idea that societies are quasi-natural beings whose problems ask for technical, not political solutions, often gets coupled with the discursive strategy of flattening, or veiling, the volitive dimension intrinsic to social exchanges. The more social arrangements and changes are seen as the result of humans making value judgments, the more difficult it is to sustain that they can effectively be understood without some assessment of the culture specific, value-laden elements constitutive of such judgments or the moral horizon against which they are made.

13 FOUCAULT, Michel. Security, Territory, Population: Lectures at the Collège de France 1977-1978 Palgrave, 2009. pp. 104-105

14 For different perspectives on the issue, see ROSANVALLON, Pierre. La Contre-Démocratie. La politique à l'âge de la défiance. Seuil, 2006. and POSNER, Richard. The Crisis of Capitalist Democracy. Harvard University Press, 2011.

15 GALBRAITH, J. K. The Age of Uncertainty: A History of Economic Ideas and Their Consequences. Houghton Mifflin, 1977. 
Performing this type of culture-based assessment represents a major hurdle to sustaining both the value-neutral character of descriptions and the quasi-natural character of society. Analyses purporting to offer a politically and morally neutral account of social events, as well as proposals for intervention in different cultures, must thus assume some form of general law presiding over human behavior which overcomes the troubling methodological consequences of culturally-bound intentionality.

From the middle of the $20^{\text {th }}$ century onwards, the rational choice theory has been increasingly used to fill this argumentative need. ${ }^{16}$ Downs' seminal article An Economic Theory of Political Action in a democracy, illuminates the intellectual move which allows this theory to perform such generalizing role. On a footnote (arguably, a rather striking place for a central definition), he offers a distinction that would be absolutely key to the viability of his whole argument:

$$
\begin{aligned}
& \text { The term "rational" in this article is synonymous with } \\
& \text { "efficient." This economic definition must not be confused } \\
& \text { with the logical definition (i.e., pertaining to logical } \\
& \text { propositions) or the psychological definition (i.e., calculating } \\
& \text { or unemotional). }{ }^{17}
\end{aligned}
$$

Rational is thus circumscribed to its economic meaning, linked to the idea of efficiency as a maximizing of resources: "Every agent in the model... behaves rationally at all times; that is, it proceeds toward its goals with a minimal use of scarce resources and undertakes only those actions for which marginal return exceeds marginal cost' ${ }^{18}$ The adoption of the economic connotation over any other reduces the number and complexity of variables (as human choices are disconnected from socio-historically embedded logical and psychological elements), thus making it much more feasible to explain and predict paths of social transformation. ${ }^{19}$

When this common (supra-cultural) rationality is accepted, then it becomes possible to assess the quality of social institutions around the world by measuring how

16

17 DOWNS, Anthony. "An Economic Theory of Political Action in a Democracy." Journal of Political Economy, vol. 65, no. 2, 1957, p. 137. JSTOR, JSTOR, www.jstor.org/stable/1827369.

18 DOWNS, Anthony. "An Economic Theory of Political Action in a Democracy." Journal of Political Economy, vol. 65, no. 2, 1957, p. 137. JSTOR, JSTOR, www.jstor.org/stable/1827369.

19 Richard Taylor, who won the Nobel Prize for economics in 2017, has importantly challenged some of these assumptions. See TAYLOR, Richard. The Winner's Curse: Paradoxes and Anomalies of Economic Life. Princeton University Press, 1994. close or how far they are from being the result of rational choices. It is also possible to suppose that conflicting interests may ultimately be overcome by reference to the common standard of rationality. This seems to be the principle underneath what has been called the contractualization of $\mathrm{Law}^{20}$ and the surge of ADR methods within national boundaries. It is also a central element in the case for global governance as an evolution taking place in the international arena.

\section{A KALEIDOSCOPIC PYRAMID: POLITICAL UNDERPINNINGS OF THE IDEA OF GOVERNANCE}

Transported into the international area the discussion on governance, and on the related notions of network and regulation becomes substantially different. In the absence of the gravitational pull of government and unconstrained by the spatial limits of the State, the pyramid, in curious kaleidoscope-manner, has indeed assumed many other forms, depending on the way observers choose to look at it.

The mainstream position considers the international space as being constituted primarily by the community of sovereign States, to which all the other players would necessarily have to make reference to. In this scenario, substantial adaptation would be necessary if one wished to still use the triad government-ordinance-pyramid to explain change. The standards and certainties of domestic law are too dissimilar from those of public international law for the explanatory force of the metaphor to survive intact.

For the international legal order, even when seen as primarily a structured system of norms, the image of a pyramid was never really appropriate. Not even in oversimplified versions of the Kelsenian chain of validation of the norms (in which the validating principle for treaties would be found in the customary law of pacta sunt servanda) the integrity of the allegory would stand. No verticality or hierarchy between the norms or the sources of law is recognized by the system.

Nor would any formal hierarchy be found between the actors of the system, the States. They enjoy identical status as law makers and the addressees of norms,

20 CHEVALLIER, J. L'Etat post-moderne. LGDJ, 2017. pp. 138139 
in a level field of sovereign equality. The idea of a government, therefore, as a central authority charged with the creation of law and its application, is absent from the system.

As a corollary to these two previous traits, one cannot speak of Law as being made of ordinances or commandments, since there is no authority to issue them, but always as a result of negotiations between States or of the accumulated practice combined with the conviction that such practice is legally binding. In a discursive reversal not exempt from irony, international Law, which was once challenged to justify its legal status exactly because it lacked exactly such elements, is now seen as a blueprint for understanding the future of Law in post-modern times.

These dynamics of international Law, perceived as intrinsically consensual, has made it a prime setting for the idea of global governance to thrive. The aging institutions of the Modern State, and the weight of government-ordinances-pyramid not being a real factor here, the contractual logic governance embodies could rapidly gain terrain. In this context, the ideological assumptions shaping such discourse tend to become even less visible as the clash with standing institutions is less evident.

In fact, essentially the same process of naturalization and neutralization takes place here. The mainstream argument suggests that due to the growing complexity of international societal life, governability cannot be insured by the formal law and institutions produced by states. Their rigidity would make them unsuitable to regulate the liquid Modernity ${ }^{21}$ of a globalized world.

The answer to a changing world would be therefore to understand, as a natural process, the rise of more flexible types of regulations, which, together with treaties and customs, will come to form the fabric of a regulatory network. The idea of adjustment, with the corollaries mentioned above, is elemental to this reading of the current change, as it is the assumption of a Darwinist-style institutional selection.

In this new scenario, the states which collectively represent the locus of international power - legitimized by the functional fiction of sovereign equality - gain the company of other governing agents, of other re-

21 For the concept, see BAUMAN, Zygmut. Liquid Modernity. Polity Press, 2000. gulators who now share with them the same horizontal field. Law becomes one component of governance, with the latter being the broader term. This move to an instrumental understanding of Law within the global governance framework works to efface their different legitimation processes in the name of the advantages of rational consensus on an efficient solution.

Here as well is at work the vision of society - this time of States - as a natural, quasi biological mechanism. Here the axiological problem stated above, of conflating description and evaluation, is also at work. Here the same strong idea of the irrelevance of ideology resonates. And, most importantly, the implications of the rational choice approach are to be seen working in their full capacity.

Such comparing of incomparable realities (Law, governance) gets reinforced and discursively naturalized by the widespread practice of creating numerical indexes and rankings to assess performance. In spite of customary disclaimers and qualifications on the way such indexes and rankings should be approached, one of their most prominent actual effects is that of making it easier to simplify the comparison of often complexly unequal realities.

An example, taken from the World Bank's Systematic Country Diagnostic may help illustrate the point. Though mindful of the potential pitfalls attached to this kind of measurement, the Guidelines in the document suggest that using such indexes may prove ultimately beneficial to all:

Benchmarking a country's performance on key development indicators against carefully selected comparators can provide useful evidence to inform the framing of key development challenges, taking into account contextual factors. Benchmarking is particularly informative when it does not limit the set of comparator countries to geographic neighbors or an arbitrary list of countries that a country might like to be compared to, but uses objective criteria to select comparators taking into account the questions the exercise is seeking to address. [...] Benchmarking certain social, buman development and governance indicators against countries that are at a similar stage of economic development might help identify areas where a country is under (or over) performing relative to its income levels. ${ }^{22}$

The language used bespeaks the tension between the intent to be respectful of national idiosyncrasies and the constraints of the neutral-natural discourse perspective

22 IBRD/IDA/IFC/MIGA Guidance - Systematic Country Diagnostic p. 7, item 28 . 
framing the whole document. Notions such as key development indicators have to be used across-borders if they are to serve at all as comparative entities. As suggested above, however, this raises again the issue of the non-neutrality of universal standards. It may indeed be very useful to decide on a few indicators to apply to analysis of every society, but the admittedly thorny task of doing so without risking incur in top-down processes seems to require novel approaches. ${ }^{23}$

This critical reappraisal of perspectives would have to take into account that the similarity supposed by $c a-$ refully selected comparators is not a fact of nature but an intellectual construction and, thus, culture-determined. In Alice in Wonderland, Lewis Carroll's (a mathematician) uses his spectacular mock-logical humor to suggest the - ultimately meaningless - possibility of comparing the most disparate realities (and find a moral in it!): "Very true,' said the Duchess: 'Alamingoes and mustard both bite. And the moral of that is--"Birds of a feather flock together." 'Only mustard isn't a bird,' Alice remarked.' 'Right, as usual,' said the Duchess: "what a clear way you have of putting things!". The comparators may indeed say more about those making the comparison than about the reality observed.

It also requires calling into question, and addressing more directly, the naturalizing drive quietly at work in the global governance logic at work in the Guidelines. The reference to "similar stage $[s]$ of economic development" echoes $19^{\text {th }}$ and $20^{\text {th }}$ versions of ideas of progress which critics have denounced as social Darwinism. As mentioned above, this unstated evolutionary belief would be at the heart of policies of intervention by global governance institutions:

This type of social Darwinism is today implemented by what managers (private and public) calls benchmarking. This "selection of best practices" consists in using one practice which has achieved better results than others as a rule to measure (benchmark), the latter. This "good practice" is itself always susceptible to be perfected, benchmarking leading to a never-ending process of emulation. ${ }^{24}$

23 DELMAS-MARTY, Mireille. Ordering Pluralism: A Conceptual Framework. for Understanding the Transnational Legal World (French Studies in International Law). Hart Publishing, 2009.

24 SUPIOT, Alain. La Gouvernance par les Nombres. Cours au Collège de France $(2012$ - 2014). Paris: Fayard - Poids et medures du monde, 2015.

p. 207.« Ce type de darwinisme est aujourd'hui mis en œuvre par ce que le management (privé et public) nomme le benchmarking. Cette "sélections des meilleures pratiques" consiste à utiliser une pratique obtenant de meilleurs résultats que d'autres, comme étalon de mesure (benchmark) ce ces dernières. Cette "bonne pratique" est elle-même susceptible d'amélioration, le benchmarking engageant
Challenges to global governance are thus substantial and profound, to a large extent because a substantial amount of the questioning, as this analysis tries to illustrate, aims at the very philosophical fabric from which this idea emerges. This acknowledgement does not necessarily translate, as it is sometimes assumed, embracing an equally problematic notion of nationalism, communitarianism, authenticity or autonomy. But it does imply suggesting that the current hegemonic mode of global governance has a tremendous - if unintended - disruptive power over local realities. The widening socio-political turmoil around the world, in special the rise of radical governments and the mounting xenophobia, seem to be, to an important measure, a response to the logic and practice that such governance has helped implement so far.

\section{References}

BAUMAN, Zygmut. Liquid Modernity. Polity Press, 2000.

CHEVALLIER, Jacques. L'Etat post-moderne. LGDJ, 2017

DE SOUZA SANTOS, Boaventura; RODRIGUEZGARAVITO, César A(orgs). Law and Globalization from Below. Cambridge: Cambridge University Press, 2005.

DELMAS-MARTY, Mireille. Ordering Pluralism: A Conceptual Framework for Understanding the Transnational Legal World (French Studies in International Law). Hart Publishing, 2009.

DOWNS, Anthony. "An Economic Theory of Political Action in a Democracy." Journal of Political Economy, vol. 65, no. 2, 1957, p. 137. JSTOR, JSTOR, www.jstor. org/stable/1827369.

FISH, Stanley. "Working on the Chain Gang: Interpretation in the Law and in Literary Criticism." Critical Inquiry, vol. 9, no. 1, 1982, p. 204. JSTOR, JSTOR, www. jstor.org/stable/1343280.

FISH, Stanley. "Working on the Chain Gang: Interpretation in the Law and in Literary Criticism." Critical Inquiry, vol. 9, no. 1, 1982, p. 204. JSTOR, JSTOR, www. jstor.org/stable/1343280.

un processus sans fin d'émulation». 
FOUCAULT, Michel. Sécurité, Territoire, Population; Gallimard, Paris, 2004.

GALBRAITH, J. K. The Age of Uncertainty: A History of Economic Ideas and Their Consequences. Houghton Mifflin, 1977.

LECHNER, Frank S.;BOLI, John. The Globalization Reader. 4th Edition. Wiley-Blackwell, 2011.

MITCHELL, W. J. T (editor). The Politics of Interpretation (A critical Inquiry Book). Chicago: University of Chicago Press Journals, 1983

OST, François; KERCHOVE, Michel van de. De la pyramide au réseau? Pour une théorie dialectique du droit. Bruxelles : Presses des Facultés Universitaires Saint Louis, 2002.
POSNER, Richard. The Crisis of Capitalist Democracy. Harvard University Press, 2011.

ROSANVALLON, Pierre. La Contre-Démocratie. La politique à l'âge de la défiance. Seuil, 2006.

SUPIOT, Alain. La Gouvernance par les Nombres. Cours au Collège de France (2012 - 2014). Paris: Fayard - Poids et medures du monde, 2015.

THALER, Richard. The Winner's Curse: Paradoxes and Anomalies of Economic Life. Princeton University Press, 1994.

WHITE, Hayden. "The Question of Narrative in Contemporary Historical Theory." History and Theory, vol. 23, no. 1, 1984. 
Para publicar na Revista de Direito Internacional, acesse o endereço eletrônico www.rdi.uniceub.br ou www.brazilianjournal.org.

Observe as normas de publicação, para facilitar e agilizar o trabalho de edição. 